\title{
Stories About Ourselves: A Collaborative, International Materials and Teacher Development Project
}

\section{Cherie Brown}

Akita International University

\section{Shamsi Ara Huda}

Daffodil International University

\section{Reference Data}

Brown, C. \& Ara Huda, S. (2021). Stories About Ourselves: A collaborative, international materials and teacher development project. In P. Clements, R. Derrah, \& P. Ferguson (Eds.), Communities of Teachers \& Learners. JALT. https://doi.org/10.37546/JALTPCP2020-12

Bangladeshi English teachers indicate that learners struggle with English reading materials because of unfamiliar cultural content presented simultaneously with unfamiliar target language. They report that emphasis on foreign texts and a lack of culturally relevant materials result in demotivated learners and poor classroom participation. Local research into this led to the design of an international collaborative teacher/materials' development project with Bangladeshi English teachers. An initial teacher-training event evolved into a long-term project, aimed at online publication of "homegrown" graded stories with a Bangladesh content focus, using high frequency English vocabulary and controlled grammatical structures. The goals were to create a bank of free, culturally appropriate graded materials for Bangladeshi learners, to train Bangladeshi teachers how to develop these, to improve participants' English and professional competencies, and to strengthen ties between participants within Bangladesh and internationally. The presentation outlines the project and provides insights from one Bangladeshi project participant.

バングラデシュの英語教師達は、馴染みの無い文化コンテンジが登場する為に、学習者が英語のリーデイング教材と格闘 している現状、また海外で作られた教科書の重用や文化的に適切な教材の不足が、学習者のやる気をそぎ、授業への低参加 率を招いていることを指摘する。この問題を現地で調査した結果、現地の英語教師との国際共同教師・教材開発プロジェク卜 が考案され、バングラデシュに焦点を合わせた内容で、使用頻度の高い英語の語彙と統制された文法構造を用いた「自国産」 のレベル別読本のオンライン出版が目的とされた。このプロジェクトの目標は、バングラデシュの学習者向けに文化的に適切
な無料のレベル別教材バンクを作成すること、バングラデシュの教師がこれらの教材を開発する方法をトレーニングするこ と、参加者の英語と職業的能力を向上させること、バングラデシユ国内および海外の参加者との繋がりを強化することである。 本稿は、バングラデシユのプロジェクト参加者の一人として、プロジェクトの概要とその考察を述べる。

his paper demonstrates a collaborative project between members of the Bangladesh L English Language Teachers' Association (BELTA) and the first author, a member of the JALT special interest group Teachers Helping Teachers (THT). The project, Stories About Ourselves (SAO), is ongoing, and aims to provide a practical means by which Bangladeshi EFL teachers can further develop their professional skills while simultaneously creating much-needed culturally relevant graded reading materials for Bangladeshi learners. It provides direct personal mentorship for Bangladeshi participants during the writing process, and opportunities for project growth along with potential for future research. On a personal level, the project has facilitated an improved understanding of Bangladeshi EFL teachers' and learners' needs for myself (Cherie Brown), based in Japan, who initiated and manages the project, and provides much needed insight into the Bangladeshi context, as I prepare for the BELTA/THT teacher development workshops that take place in Dhaka, and various regions of Bangladesh each year.

\section{Literature Review}

The SAO project reflects one practical attempt to apply principles emerging from a shift in focus within the field of EFL teaching and learning, as these relate to issues of cultural relevance, identity, ownership of English, the content of teaching/learning materials, and teacher empowerment.

In a global context where the traditional divisions between native and non-native speakers of English are being challenged, there is a growing emphasis on learning more about the possible contributions that nonnative English-speaking educators can make to the profession (Llurda, 2009). In particular, questions about the role of cultural content in EFL teaching are increasingly frequent (Bayyurt, 2006), with non-native teachers 
JALT2020

COMMUNITIES OF
TEACHERS \& LEARNERS of English and learners alike more vehemently stating their preference for culturally familiar materials over those that reflect only native speaker contexts, values, and norms. Akter (2018), a Bangladeshi EFL academic, stated, for example,

Although English has become an international language, there seems to be little emphasis, yet, on the parallel development of teaching materials promoting local cultural content, in spite of the fact that there is a growing recognition of the importance of including local or source culture. (p. 62)

Not only is there an apparent lack of culturally relevant teaching/learning materials, but often the assumption is that British and American standards of English are the norms to which learners should aspire because that is what learners are mostly exposed to. Hu (2004) illustrates this practice by saying that "the belief has been inculcated into them... by all the language books they use," (p. 31), a belief that may simply reinforce the view of English as belonging to the "other." Citing the work of McKay (2002), Matsuda writes, "the inner circle alone can no longer provide adequate cultural content in EIL teaching, and thus materials from the source culture (i.e. the learners' culture)... must be included" (2002, p. 170).

Much earlier, Widdowson (1994) had drawn attention to the need to move away from the native speaker-centric view of English as belonging predominantly to so-called inner circle countries (i.e. countries which have traditionally been perceived as predominantly using English as a first language, such as the UK, the USA, Australia and New Zealand; Kachru, 1992). Subsequently, Dogancay-Aktuna (2006) has described this growing trend as a paradigm shift within English language teaching. EFL learners commonly express a desire or need to acquire better English language skills, acknowledging that English is an intrinsic part of modern life for members of a global community, and as they learn it, they may increasingly view English as "theirs." In fact, assuming a new identity as an English speaker may be seen by many learners as desirable. This reflects the reality that individuals typically express a multiplicity of identities that change over time, both within the self and across varying contexts (Norton, 2013).

However, the ability to express the self in the enactment of multiple identities, including any new identity one creates as an English speaker, does not necessarily mean that learners fail to notice the biases of the materials they use. Nor does it mean they willingly either accept these biases or what they may perceive as an inherent pressure within foreign textbook content to view and assimilate the foreign values, practices and beliefs presented there, as if these are desirable. Given the option, many may prefer material that more closely reflects their own cultural contexts and who they currently see themselves to be, not who Western English language publishers appear to assume they want to be. Akter and Begum's study (2017) on learner preferences for culturally familiar reading materials lends weight to this idea.

Moreover, the acquisition of English is increasingly less likely to be considered as a conduit to integration into a target native speaking community, but rather as a means to facilitate intercultural global communication. McKay explains it thus,

Learners of an international language do not need to internalize the cultural norms of native speakers... the ownership of an international language becomes de-nationalized; and the educational goal of learning it is to enable learners to communicate their ideas and culture to others. (McKay, 2002, p. 12)

A rationale for the development of culturally relevant learning materials thus appears well-established, and it was this kind of theoretical foundation that provided a basis for the collaborative SAO project. However, in developing culturally appropriate reading material for the Bangladeshi context, several other features also needed to be considered.

In the first instance, the impact of cultural schema on learners' reading skills' development should be considered, since learner's background knowledge is a critical element in building reading comprehension (Fisher \& Frey, 2009). Thus reading materials presenting familiar cultural content are likely to be more efficacious since learners will not have to struggle with unfamiliar concepts while simultaneously decoding unfamiliar target language (Akter \& Begum, 2017).

Additionally, Akter and Begum's study also indicates a link between identity and motivation. In a subsequent report, Akter claimed that prior to the study "Bangladeshi students often do not demonstrate much interest in, or motivation to read English texts." However, after introducing culturally familiar reading materials, she describes her learners' more positive responses, saying, "their native culture-based texts help them to visualize the situations described in the text and activate their prior knowledge... (which) increases their eagerness to learn." (Akter, 2018, p. 69).

A further consideration underpinning the SAO project was the need to provide suitably graded material for various learner levels featuring high frequency English vocabulary. Waring (2009) describes the case for extensive graded reading as "inescapable" because,

Recent vocabulary research shows that learners need to meet massive amounts of language to learn not only single words but also their collocations, register and so forth... (and) neither intentional learning nor course books... can cover the vast 
JALT2020

COMMUNITIES OF
TEACHERS \& LEARNERS

volume of text the learners need to meet without Extensive Reading... learners need to gain their own sense of language and this cannot be gained from only learning discrete language points, rather it must, and can only, come from massive exposure in tandem with course books. (para. 1)

Not only are graded readers important because of the added exposure to the target language that they afford learners, but by virtue of their design, they also offer learners the opportunity to meet high frequency vocabulary in greater measure. As Nation (2001) reminded us, "high frequency words... are so important that considerable time should be spent on them by teachers and learners" because of the wide "coverage (they) provide for various kinds of text." (pp. 16, 17)

In addition, an awareness of the interdependence of language, storytelling and identity was key to the kinds of materials that the SAO project aimed to produce. Zalmay (2017) reminded us that,

Language is not simply an assortment of words but an entity that connects an individual to (one's) family, identity, culture, music, beliefs and wisdom. It is the carrier of history, traditions, customs and folklore from one generation to another.

Without language, no culture can sustain its existence. Our language is actually our identity. (para. 3)

If language is identity, then, for a thoughtful, non-native speaker of English, several questions may arise. "Who am I ... in English?" "Who do I want to be ... in English?" and "What is my identity... in English?" For Akter and Begum's students, the unfamiliar cultural content and linguistic complexity of the materials they were expected to study had led to demotivation and poor class participation. They had failed to see anything of themselves in the reading texts they were required to use, thus, also failing to make meaningful connections with the material in a manner that would enhance their potential to learn. English had failed to become, for them, a desirable medium through which they could create a deeper understanding of themselves, and possibly a new and richer sense of personal identity.

Akter and Begum's study indicated that the dependence on English language materials that focus only on external foreign content, while useful for informing learners about life beyond Bangladesh in English language contexts, or for educational purposes relating to potential participation in the global community, appeared to reinforce this apparent lack of interest and limited vision. This is especially likely to be the case if these resources are not balanced with material that does reflect the lived experiences and personal identities of Bangladeshi learners themselves. On the other hand, the incorporation of culturally appropriate stories written in English, in which learners see themselves reflected, may contribute towards changing attitudes, helping learners move towards constructing a broader sense of identity which includes an understanding of who they are in relation to English, and, as they use the language, who they are "in English."

This leads us to consider the means we need to employ, by which learners may move towards better English skills and the creation of an identity in English, while supporting learners' existing identities. Breen (2015) asserted,

Identity is constructed through stories... Storytelling isn't just a childhood pastime it continues throughout adulthood as a means of defining ourselves... and ...the stories we tell about ourselves change throughout our lives, reflecting our family background, culture and relationships.”. Similarly, “...stories... communicate who we are ... (and) also help construct our own understanding of who we are. (paras. 1-2)

A final but no less important consideration was the issue of teacher empowerment. Inherent in the SOA project was the belief that Bangladeshi teachers themselves, with appropriate guidance and support, could create the kinds of materials they and their learners needed. In fact, according to Zacharias (2005), this is an "immediate need," especially considering the commonly held view that foreign language learning textbooks are superior to homegrown materials, and the current lack of such materials in the first instance.

The challenge for the SOA project then, was to find a suitable means to address these professional development needs within the Bangladeshi context, while simultaneously creating a growing bank of materials that reflect a local cultural flavour, and, in light of the findings of research, are pedagogically sound.

\section{Background: The Stories About Ourselves Project}

In 2017, the first author attended a presentation by Akter and Begum, two Bangladeshi academics, at the annual Nepal English Language Teachers' Association (NELTA) in Kathmandu, in which they outlined their action research project with Bangladeshi university learners in their reading classes. As mentioned, their study derived from their observations of a general lack of motivation and participation on the part of their learners, along with concerns about generally low levels of English proficiency, in spite of the fact that their learners had received several years of prior formal English language education. Additionally, they questioned the nature and value of the Western commercial reading textbooks they were required to use, describing how their learners struggled with the unfamiliar cultural content while simultaneously attempting to decode new target language. 


\section{By way of intervention, Akter and Begum introduced homegrown reading texts in} English reflecting Bangladeshi cultural content, and observed classroom behaviors and gathered learners' feedback. Though their study was small, and did not attempt to quantify any improvements in language proficiency, they did find that learners preferred reading materials with culturally familiar content, and their motivation increased. However, there was a great lack of such materials. To overcome this deficiency, they concluded that teachers would need to be trained in how to produce the required materials (Akter \& Begum, 2017)

Following their presentation, I (the first author) approached Ms. Akter, and suggested that by working with Bangladeshi teachers, I might be able to help them develop the kinds of materials that they needed. My own interest in high frequency vocabulary acquisition and experience as a teacher of academic English reading skills in Japan, and of using extensive graded reading materials, led me to believe that a collaborative project which built Bangladeshi teachers' materials' development skills, and a bank of culturally relevant graded reading materials, might be a real possibility.

Additionally, my experience as a participant in the co-hosted BELTA/THT annual teacher development workshops had taken me to Bangladesh several times. My established contacts with colleagues in BELTA meant that I may be able to enlist their support, so that by working together we might be able to create the materials that appeared to be needed. If we could grade these to various proficiency levels, and make them freely available online, teachers across the entire Bangladeshi education system and learners of all levels of ability would be able to make use of them.

I had observed, in some of the Bangladeshi schools I had visited, that some reading materials with culturally relevant content did exist, but that these were not graded for difficulty. Moreover, these existing materials were not available to all schools equally, since they were in hard-copy format, and were also somewhat dated. Therefore, they were unlikely to have been in widespread use in English classrooms across the country.

Added impetus to undertake the project came from informal anecdotal accounts by Bangladeshi teachers I had met during THT teacher training events, in which they had expressed their concern about the quality of their own English language skills. Teachers had also expressed a desire to update their professional knowledge and improve their own professional practise. It seemed clear that a project in which Bangladeshi teachers could be directly supported while creating their own materials would enable Akter and Begum's call for culturally relevant materials and teacher development to be realized.

\section{Getting Started}

The opportunity to begin the project did not arise until late 2018 when I again visited Dhaka to participate in the BELTA/THT teacher training workshops. Prior to the visit, I had sought permission from the event organisers to include a separate, three-hour workshop, additional to the THT program, in which to explain the idea for the project and hopefully begin the process of training interested participants in how to produce culturally relevant graded reading texts for Bangladeshi learners. Fortunately, members of the BELTA executive were enthusiastic, and approached a number of university EL teachers to solicit their involvement. Interested persons were informed that their involvement might well continue beyond the initial training event, and in the end, nine people agreed to participate.

During the training workshop, I explained the project idea and its background, then demonstrated how to use an original Bangladeshi story, in this case a story kindly provided by one of Ms. Akter's students, analysed it using the online vocabulary analysis tool "Web Vocabprofile" created by Cobb (2002), then adapt and grade it for classroom use. Workshop participants were then given the opportunity to begin writing their own short story, ensuring that it reflected life in Bangladesh in some way, and to practise using the vocabulary analysis tool. They were then asked to send their completed story to me for further editing and adaptation as required, with a view to future online publication. In addition, participants were asked to indicate their willingness to continue writing and submitting stories for publication on a website that was yet to be developed. We exchanged contact details, set up a closed Facebook group so we could remain in touch informally, and so the Stories About Ourselves project was born (Brown, 2020).

In discussion with the workshop participants, and over time, some clear project goals emerged. These included:

- To encourage Bangladeshi teachers to see stories with a local cultural flavor as worthy material for use in the language classroom.

- To encourage Bangladeshi teacher-writers to begin to create their own stories, maintaining a Bangladeshi focus.

- To demonstrate and train Bangladeshi teacher-writers how to grade the stories they write to levels appropriate for their learners.

- To publish stories (and other material) written by Bangladeshi writers on a dedicated, Bangladeshi-based website for teachers across Bangladesh to use for free. 
JALT2020

COMMUNITIES OF
TEACHERS \& LEARNERS

Brown \& Ara Huda: Stories About Ourselves: A Collaborative, International Materials and Teacher Development Project
- To establish a committed group of writers who would continue to produce material in the long term.

- To continue to expand the range of stories, maintaining the Bangladeshi content focus.

- To provide Bangladeshi teacher-writers with ongoing (distance) mentoring and editing support as they produced their materials.

- To encourage a wider range of Bangladeshi English language teachers and writers to submit their stories and/or use the materials as classroom teaching/learning resources.

In achieving these goals, it was also hoped that we might have better opportunities to observe more closely whether EL stories with a Bangladeshi focus, pitched at an appropriate level, might demonstrate improved learner attitudes towards English and learners' efforts to acquire it. We might also be able to investigate how such stories shape learners' self-perceptions as non-native users of the language, and at the same time, study the impact of participation in the process of creating such materials on the professional growth and self-perceptions of Bangladeshi teachers of English. Researching these areas of interest more formally is an increasing possibility with the expanding bank of materials now being provided in the SAO project, and the steadily increasing number of writers who are contributing.

\section{Outcomes to Date}

Overall, the SAO project has worked successfully towards three clear objectives. The first goal was to create a growing bank of free, culturally appropriate graded reading materials for EL learners in Bangladesh. This goal remains in place, and the number of stories and other reading texts continues to increase. Thanks to the generous support of the BELTA Executive Board, there is now a live website which is accessible from two points, the Stories About Ourselves website at https://www.stories.belta-bd.org/ and via a live portal on the BELTA homepage at https://www.belta-bd.org/. All materials are free, have been graded to learners' levels using Cobb's vocabulary analysis tool (Cobb, 2002), and grammatical guidelines provided by major graded reader publishers such as Penguin (Pearson Longman, n.d), and have accompanying high frequency word lists and follow up activities, such as comprehension and critical thinking questions and activities that utilize other skill areas such as speaking and writing. The material may be used for either extensive reading or more intensive study, as users prefer.
The aim to train Bangladeshi teachers in materials' development while simultaneously improving their English and professional competencies continues. This is now perceived as a long-term goal. In future, maintaining the project will require the recruitment of a competent volunteer professional in Bangladesh to take over the editing and administrative role, so that it eventually becomes completely based and managed in Bangladesh. Finding this person is a medium-term goal, and will need to be managed in concert with BELTA colleagues and under their advice.

The final objective has been achieved, though it continues to be developed. This is the goal of strengthening ties between EL teachers, academics and other contributors, both within Bangladesh and internationally. Strong professional and personal connections have been forged, which will need to be nurtured and developed further for the project's ongoing success.

In terms of insights gathered from the project so far, while it is necessary to establish clear project objectives when undertaking a project such as SAO, it is also important to recognize that collaboration across international boundaries poses its own unique challenges. Working in different time zones, and juggling project tasks with other more immediate professional responsibilities, and managing participants' conflicting work schedules, means that such a project must be allowed to evolve in an organic way at its own pace. It is necessary for all participants to be both patient and committed, since voluntary involvement means fitting story writing, editing and project management around other obligations. However, having something tangible that demonstrates real progress, in this case the advent of the website, gave everyone the chance to see a visible product that showcased their efforts. This certainly built a greater level of motivation and commitment on the part of all involved, and since then, the number of contributors has grown rapidly.

Teacher-writers also describe how their involvement in the project has helped them to hone their English skills as well as their professional capabilities. Informal feedback from project participants and BELTA members via social media indicate that teachers across Bangladesh are beginning to learn about the existence of the materials. This has been greatly facilitated by the use of focused Facebook groups to share links to stories and website content. Teachers in a number of universities, who have greater flexibility in the selection of course materials, are also beginning to provide positive informal feedback as they use the materials. However, more data needs to be gathered.

Furthermore, the stories and other reading materials that the SAO website provides, contain background information about the project, pages outlining writers' profiles, a 
set of writing guidelines for prospective contributors, and contact details to connect site users with the project manager (currently the first author). Teacher-writers continue to make helpful suggestions about how to improve the website, for example, one such suggestion was including downloadable PDF files allowing users to print hard copies. Writers share their stories on their own social media platforms, and as project participants, with a strong sense of ownership, are rightly proud of their achievements. One such person is Shamsi Ara Huda (the second author), who participated in the introductory workshop in 2018, and is a founding member of the original writing group. She has become one of the most prolific contributors to the SAO website, and has used several of the project materials with her own classes. Shamsi Ara Huda shares her insights and experiences of the project below.

\section{Perceptions of a Project Participant}

I consider myself privileged and honored to have participated in the project, Stories About Ourselves. My involvement with the project, in fact, has fulfilled my dream of becoming a short story writer, a dream which I have cherished for more than fifteen year since I was a student of the Department of English of University of Dhaka.

Since my involvement with the project in 2018 through the BELTA/THT training workshop facilitated by Professor Cherie Brown, I have found myself developing not only as a story writer but also as a materials developer for Bangladeshi English language learners. Earlier, I had come across the principles of Bloom's taxonomy (Anderson et al., 2001), but I did not have any idea how to implement those principles in designing English language practice activities to promote Higher Order Thinking Skills (HOTS). With the help of Professor Brown's dedicated efforts, I have learnt how to analyse a text using Web vocabprofile, an online vocabulary analysis tool created by Cobb (2002), and grade it for different levels of learners.

The spirit of collaboration is the most attractive component of this project to me. Besides, the inclusion of writers of different age groups has added an extra dimension to the project. When I had used several materials for the project in my classes, the improvement in the rate of students' participation was spectacular. The students were found to associate themselves personally with the reading materials of Stories About Ourselves because of the Bangladeshi cultural component of the materials. Their attachment to the materials inspired them to read, write, speak and listen to others' opinions, transcending their linguistic limitations, which is quite rare in their usual English language classes where they are exposed to culturally unfamiliar commercial texts.
With the support of BELTA (Bangladesh English Language Teachers Association), when the project, Stories About Ourselves became tangible in the form of the website, I received compliments from my students, colleagues and friends from home and abroad, eulogizing the renewal of different Bangladeshi cultural components prevalent in the materials of the project. Some of the faculty members of my institution, Daffodil International University, Dhaka, Bangladesh have specifically pointed out the potential of using these culture-based graded reading materials in multi-modal platforms both intensively and extensively.

The reading texts along with the subsequent activities are made available online, enabling teachers at all levels of the education system in Bangladesh, and learners at all levels of ability to utilize them. In the BELTA/THT 2020 teacher training event, some of the teachers raised concerns about how they can accommodate these materials to the fixed curriculum of Bangladeshi primary, secondary and higher secondary English courses. Resolving this will be a challenge in the near-future.

The expansion of the project till this date, navigating the challenges of time-zone difference, meticulous professional responsibilities and continuity of voluntary spirit, will eventually be proof of its further effectiveness. I believe the personal and professional ties of this example of internationalism will be strong and thus stimulate teachers' agencies in mediating constructive changes in the curriculum development of the education system in Bangladesh.

\section{Moving Forward}

From a small group of nine Bangladeshi participants, the number of writers has grown to (currently) 22 writers, several of whom have submitted more than one piece of writing. In addition to teacher-writers, we now have several student-writers, ranging in age from elementary school to university level whose work has been submitted by their teachers and mentors. The project began with only one story, and now has 40, with more to come. Both fiction and non-fiction are represented at each level, along with poetry. Future materials' development may also include audio files of the stories, plays and songs, and all stories have original visual materials added for interest.

In order to record statistics of use, a visitor counter is installed, which will keep track of which stories are favored, and we hope to be able to record the number and kind of downloads as well as gather data about the regional location of website visitors and users in Bangladesh. Apart from analysis of statistical data relating to site use, there are several possibilities for future research projects that investigate both learners' preferences, as 
well as quantifiable learning outcomes. Research into learning outcomes in relation to the SAO materials can now be done by Bangladeshi researchers themselves, since these are now readily available to them. Another possible future study might also investigate the impact of project participation and the mentoring process on changes in teachers' professional and linguistic self-perceptions as users of English. Data is currently being gathered towards that end.

It is our hope, by sharing the SAO story here, that it will continue to inspire not only Bangladeshi teachers and learners to value and share their own stories as English language learning tools, but also colleagues in other so-called outer circle settings to boldly initiate similar projects of their own. If this eventuates, it will lead to more culturally relevant materials' development, and such materials can then be utilized to better meet their needs and those of their EFL learners.

\section{Bio Data}

Cherie Brown teaches at Akita International University, Akita, Japan and is the Stories About Ourselves Project Manager, and a regular Teachers Helping Teachers presenter in Bangladesh. Her interests include teacher development, vocabulary acquisition, and EFL/ESL materials' development. cbrown@aiu.ac.jp

Shamsi Ara Huda teaches at Daffodil International University, Dhaka, Bangladesh. She is an Executive Board member of BELTA. Her research interests include CALL (Computer Assisted Language Learning), literature in the language classroom, materials' design, reflective teaching, and teacher education. shamsi@daffodilvarsity.edu.bd

\section{References}

Anderson, L. W., Krathwohl, D. R., \& Bloom, B. S. (2001). A taxonomy for learning, teaching, and assessing: A revision of Bloom's taxonomy of educational objectives (Complete ed.). Longman.

Akter, S. (2018). Culturally inclusive material for non native speaking countries: A Case Study in the Context of Bangladesh. THT Journal, 6(1), 57-78.

Akter, S., \& Begum, T. (2017). Effectiveness of homegrown material in non-native speaking countries, NELTA 2017. Presentation delivered on February 24 at Premier International IB World School, Khulmatar, Lalitpur, Nepal.

Bayyurt, Y. (2006). Non-native English language teachers' perspectives on culture in English as a foreign language classrooms. Teacher Development, 10(2), 233-247. Retrieved from https://www. tandfonline.com/doi/full/10.1080/13664530600773366?scroll=top\&needAccess=true
Breen, A. (2015). How storytelling impacts our identities. University of Guelph Website. Retrieved from https://news.uoguelph.ca/2015/07/how-storytelling-impacts-our-identities/.

Brown, C. (2020). Stories about ourselves. Retrieved May 29, 2021, from https://www.stories.beltabd.org/

Cobb, T. (2002). Web vocabprofile. Retrieved from https://www.lextutor.ca/vp/.

Dogancay-Aktuna, S. (2006). Expanding the socio-cultural knowledge base of TESOL teacher education. Language, Culture and Curriculum, 19(3), 278-295.

Fisher, D., \& Frey, N. (2009). Background knowledge: The missing piece of the comprehension puzzle. Heinneman.

Hu, X. H. (2004). Why China English should stand alongside British, American and other 'world Englishes'. English Today, 20(2), 26-33. https://doi.org/10.1017/S0266078404002056

Kachru, B. (1992). The other tongue: English across cultures. University of Illinois Press.

Llurda, E. (2009). Attitudes towards English as an international language: The pervasiveness of native models among L2 users and teachers. In F. Sharifan (Ed.), English as an international language: Perspectives and pedagogical issues (pp. 119-134). Multilingual Matters.

McKay, S. (2002). Teaching English as an international language: Rethinking goals and approaches. Oxford University Press.

Matsuda, A. (2002). Representation of users and uses of English in beginning Japanese EFL textbooks. JALT Journal, 24(2), 80-98. https://doi.org/10.37546/JALTJJ24.2-5

Norton, B. (2013). Identity and language learning: Extending the conversation. Multilingual Matters.

Pearson Longman. (n.d.). Penguin graded reader guidelines. Retrieved May 29, 2021, from https:// www.pearson.ch/download/PR_Teacher_Support_Guide_CH.pdf

Waring, R. (2009). The inescapable case for extensive reading. Retrieved from http://www. robwaring.org/er/what_and_why/er_is_vital.htm

Widdowson, H. G. (1994). The ownership of English. TESOL Quarterly, 28, 377-389. https://doi. org $/ 10.2307 / 3587438$

Zacharias, N. (2005). Teachers' beliefs about internationally-published materials: A survey of tertiary English teachers in Indonesia. RELC Journal, 36(23), 23-37. https://doi. org $/ 10.1177 / 0033688205053480$

Zalmay, K. (2017). Language and identity. The News International. Retrieved from https://www. thenews.com.pk/print/185439-Language-and-identity 